\title{
Engineering of cyclodextrin glucanotransferases and the impact for biotechnological applications
}

\author{
Hans Leemhuis • Ronan M. Kelly $\cdot$ Lubbert Dijkhuizen
}

Received: 27 June 2009 /Revised: 25 August 2009/Accepted: 25 August 2009 /Published online: 18 September 2009

(C) The Author(s) 2009. This article is published with open access at Springerlink.com

\begin{abstract}
Cyclodextrin glucanotransferases (CGTases) are industrially important enzymes that produce cyclic $\alpha-(1,4)$-linked oligosaccharides (cyclodextrins) from starch. Cyclodextrin glucanotransferases are also applied as catalysts in the synthesis of glycosylated molecules and can act as antistaling agents in the baking industry. To improve the performance of CGTases in these various applications, protein engineers are screening for CGTase variants with higher product yields, improved $\mathrm{CD}$ size specificity, etc. In this review, we focus on the strategies employed in obtaining CGTases with new or enhanced enzymatic capabilities by searching for new enzymes and improving existing enzymatic activities via protein engineering.
\end{abstract}

Keywords Amylase - Biocatalysis · Directed evolution . Glycoside hydrolase $\cdot$ Protein engineering $\cdot$ Starch

\section{Introduction}

Cyclodextrin glucanotransferases (CGTases; EC 2.4.1.19) convert starch into cyclic $\alpha$-1,4-glucans, called cyclodextrins (CDs). Cyclodextrins were identified in 1891 and structurally characterized in the preceding years. The main products of

\section{H. Leemhuis $\cdot$ L. Dijkhuizen $(\square)$}

Microbial Physiology, Groningen Biomolecular Sciences, and Biotechnology Institute (GBB), University of Groningen, Haren, The Netherlands

e-mail: L.Dijkhuizen@rug.nl

R. M. Kelly

Dublin-Oxford Glycobiology Laboratory, NIBRT,

Conway Institute, University College Dublin,

Dublin, Ireland
CGTases are $\alpha-, \beta-$, and $\gamma$-CDs, composed of 6,7 , or 8 glucose residues, although, much larger cyclic glucans are produced in the early phases of the reaction (Terada et al. 1997; Zheng et al. 2002; Qi et al. 2007). In nature, certain bacteria and archaea presumably excrete CGTases to monopolize on the starch substrate, converting it into CDs, which cannot be utilized by competing microorganisms (Pajatsch et al. 1999; Hashimoto et al. 2001).

Cyclodextrins have numerous applications in the pharmaceutical, cosmetics, and food and textile industry, etc., as reviewed (Martin Del Valle 2009; Li et al. 2007; Biwer et al. 2002), because of their capacity to encapsulate hydrophobic molecules within their hydrophobic cavity. Encapsulation is used to solubilize hydrophobic molecules in water (CDs have a hydrophilic outside), which is particularly advantageous as many drug molecules are poorly soluble in water (Loftsson and Duchene 2007), or to protect guest molecules from light, heat, or oxidizing conditions (Astray et al. 2009). Cyclodextrins are also used to lower the volatility of odor molecules in perfumes and room refreshers for controlled release of the odor. In the chemical industry, CDs are used in the separation of enatiomers to extract toxic chemicals from waste streams (Martin Del Valle 2009) and in soil bioremediation (Fava and Ciccotosto 2002). Various other applications of CDs include the suppression of undesirable (bitter) tastes and the extraction of compounds such as cholesterol from foods (Szente and Szejtli 2004; Szejlti and Szente 2005).

\section{CGTases}

Cyclodextrin glucanotransferases are members of the largest family of glycoside hydrolases acting on starch and related $\alpha$-glucans, glycoside hydrolase family 13 (Stam 
et al. 2006) (http://www.cazy.org). The first 3D structure of this enzyme (Klein and Schulz 1991) revealed that CGTases are five domain proteins with the active site located at the bottom of a $(\beta / \alpha)_{8}$-barrel in the A domain. Substrates bind across the enzyme's surface in a long groove formed by the domains A and B that can accommodate at least 7 glucose residues at the donor subsites and 3 at the acceptor subsites (Fig. 1, labeled -7 to +3 ) as revealed by kinetic studies and crystal structures of substrate/inhibitor/ product-CGTase complexes (Bender 1990; Kanai et al. 2001; Leemhuis et al. 2003a; Wind et al. 1998; Schmidt et al. 1998; Uitdehaag et al. 1999b). The C-terminal region of CGTases is formed by $\mathrm{C}, \mathrm{D}$, and E-domains. The function of domain $\mathrm{D}$ is unknown, domain $\mathrm{C}$ has been implied in substrate binding (Penninga et al. 1996), and domain E is a raw starchbinding domain (Penninga et al. 1996; Dalmia et al. 1995; Chang et al. 1998). The E-domain is classified as a family 20 carbohydrate binding module (CBM20) (Cantarel et al. 2009; Machovic and Janecek 2006) (http://www.cazy.org).

Cyclodextrin glucanotransferases cleave the $\alpha-1,4-$ glycosidic bonds between the subsites -1 and +1 in $\alpha$-glucans yielding a stable covalent glycosyl-intermediate bound at the donor subsites (Fig. 1) (Uitdehaag et al.

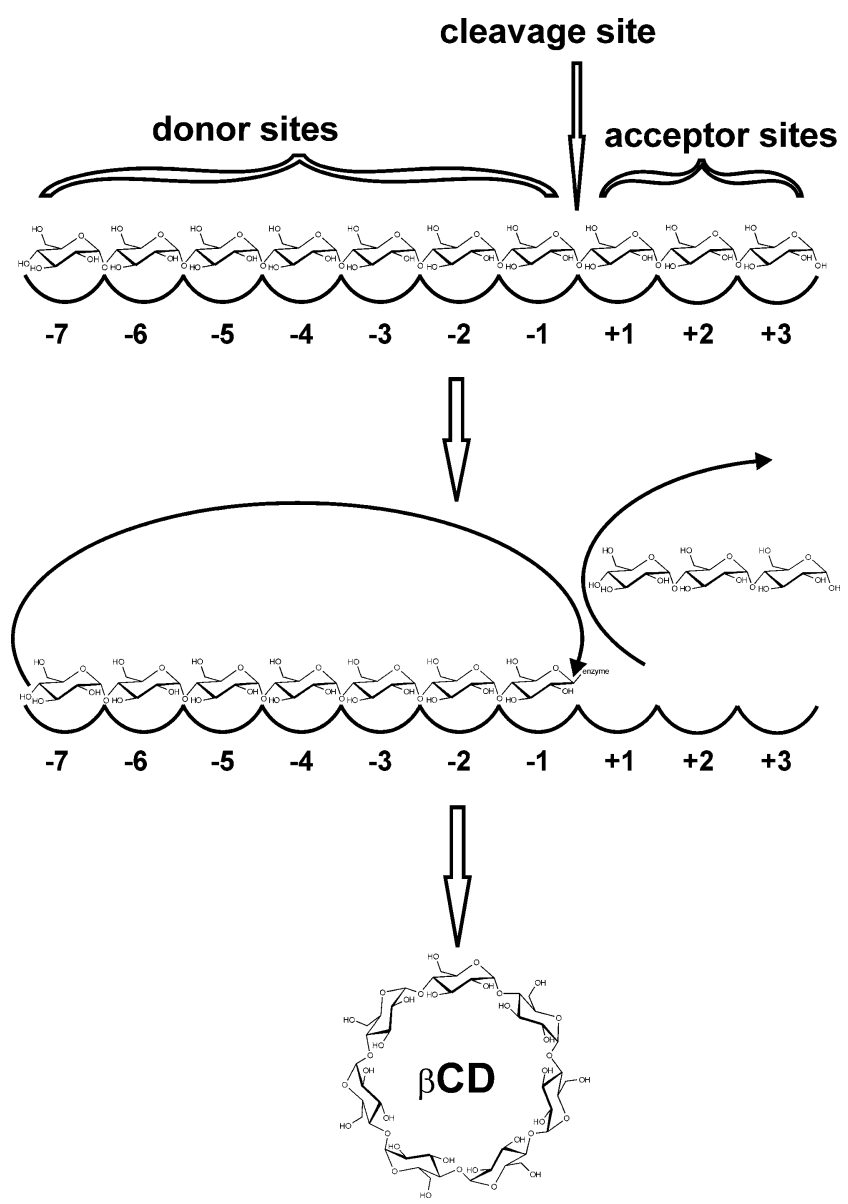

Fig. 1 Schematic view of CD formation by CGTase 1999a). The glycosyl-intermediate is then transferred to the 4-hydroxyl of its own nonreducing end forming a new $\alpha-1,4$-glycosidic bond to yield a cyclic product (Fig. 1). Cyclodextrin glucanotransferases can also transfer the glycosyl-intermediate to a second $\alpha$-glucan yielding a linear product (disproportionation) or to water (hydrolysis). In addition, CGTase can degrade CDs by opening the CD ring and transferring the linearalized $\mathrm{CD}$ to a sugar acceptor to yield a linear oligosaccharide (coupling). The large amount of structural information together with site-directed mutagenesis data have been used to elucidate the mechanistic functions of the residues at the catalytic center of CGTases (e.g., donor subsite -1) (Nakamura et al. 1993; Leemhuis et al. 2003c; Klein et al. 1992; Haga et al. 2003). However, as these mutations generally resulted in very low catalytic proficient CGTase mutants, they are not discussed here. Mutagenesis studies affecting reaction specificities are discussed below.

\section{CD production}

Cyclodextrins are produced in thousands of tons from starch annually by several manufactures, and demands are still rising. The starch is first liquefied, usually via an energy consuming jet-cooking step (Buchholz and Seibel 2008) (Fig. 2). Unfortunately, the total conversion of starch into CDs is closer to $50 \%$ than $100 \%$. One of the reasons for this lack of efficiency is that CGTases have difficulty in bypassing the $\alpha$-1,6-branches in amylopectin yielding CGTase limit dextrin (van der Maarel et al. 2002). The addition of isoamylase or pullulanase debranching enzymes increases the accessibility of the amylopectin fraction of starch, thus, increasing the CD yield (Rendleman 1997). Cyclodextrin yields are also limited due to enzyme product inhibition (Leemhuis et al. 2003a; Gaston et al. 2009) and breakdown of CDs by CGTases into linear oligosaccharides in the coupling reaction. The effects of both product inhibition and $\mathrm{CD}$ degradation are minimized by keeping the $\mathrm{CD}$ concentrations in the reactor low, which is generally achieved by adding complexing agents leading to the precipitation of the CDs. Moreover, the type of complexing agent used strongly influences the ratio of $\alpha-, \beta-$, and $\gamma-\mathrm{CD}$ produced, for details see Blackwood and Bucke (2000), Biwer et al. (2002), and Zhekova et al. (2009). The breakdown of CDs is reduced further by restricting the accumulation of short oligosaccharides through the use of CGTases with low hydrolytic activity. Indeed, it has been shown that at high concentrations of saccharides, CGTases do not produce CDs from starch (Martin et al. 2001).

The other major issue in $\mathrm{CD}$ production is that CGTases produce a mixture of CDs. A selective purification step is, thus, required to obtain pure $\alpha-\mathrm{CD}, \beta-\mathrm{CD}$, or $\gamma-\mathrm{CD}$, 


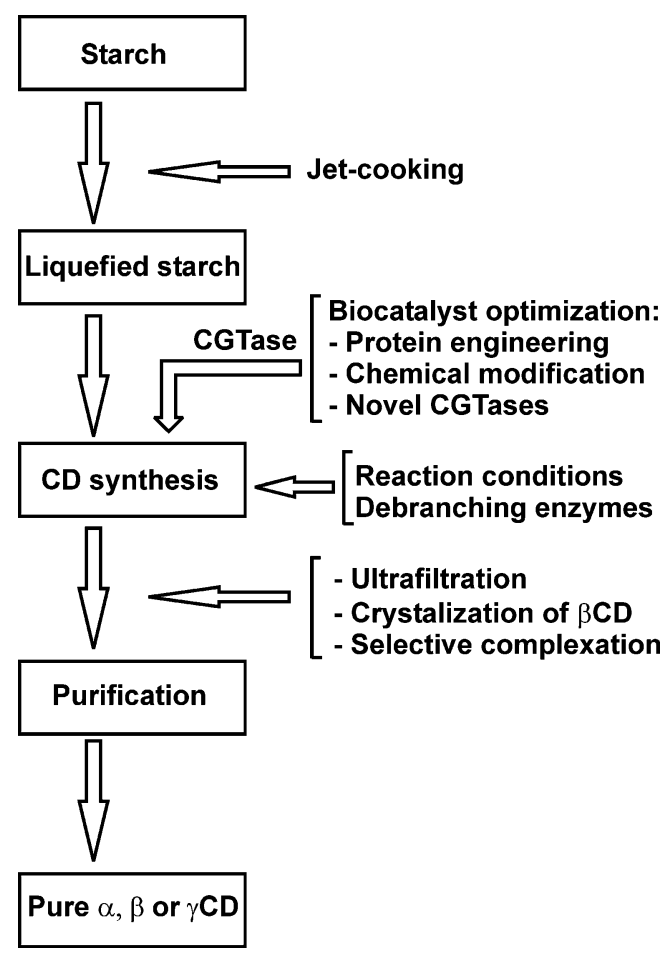

Fig. 2 Flow scheme of CD production. Highlighted are the steps where protein engineers and process controllers can influence the process efficiency

through the use of complexing agents during CD synthesis and the variation in solubility of the different CDs to allow selective precipitation (Matioli et al. 2000; Lee and Kim 1992; Son et al. 2008). The source of CGTase is the key factor in the type of CDs produced (Table 1), along with reaction parameters such as the type of starch used, the buffer composition, reaction temperature, and $\mathrm{pH}$ (Qi et al. 2004; Kamaruddin et al. 2005; Alves-Prado et al. 2008).

\section{Searching nature for better performing CGTases}

As the origin of the CGTase is the key factor in determining the ratios at which the different CDs are produced, scientists are searching nature for better performing CGTases. Moreover, novel CGTases may be better suited to the various industrial processing parameters, including substrate conversion, stability, and activity, than the currently available enzymes. There are 3 approaches to identify novel CGTases: genome mining of DNA databases, cloning environmental DNA in expression vectors and identifying recombinant clones displaying CGTase activity, or isolating bacteria/archaea expressing CGTase activity. Today CGTases of about fifty microorganisms have been (partly) characterized for CD specificity (Table 1). Fifteen of these enzymes were identified in the last 2 years, displaying a broad variation in optimal reaction $\mathrm{pH}$, temperature, stability, and CD size specificity. Despite the availability of a large number of these enzymes, a CGTase that requires little or no reengineering for industrial optimization has yet to be identified. The CGTase from Bacillus clarkii, for example, was shown to produce approximately $80 \% \gamma$-CDs (Takada et al. 2003). However, its overall conversion of starch into CDs was low at $14 \%$.

\section{Chemical modification, immobilization, and enzyme cross-linking}

Before recombinant DNA technologies were developed, proteins engineers relied on chemical modification of amino acids such as lysine, cysteine, etc., to improve enzyme function and to gain insights into functionally important residues. When combined with mass spectrometry, one can determine exactly which amino acid residues are modified, as shown for Bacillus circulans DF 9R CGTase (Costa et al. 2009). Chemical modifications of amino acids can have various effects on the reaction specificity as demonstrated for Thermoanaerorbacter CGTase, where succinylation and acetylation enhanced the transglycosylation (Alcalde et al. 2001) and hydrolytic activities of the enzyme, respectively (Alcalde et al. 1999). Chemical modification is also the first step in the synthesis of cross-linked enzyme crystals, which are insoluble particles that retain catalytic activity under harsh conditions such as extreme $\mathrm{pH}$, high temperature, and high solvent concentrations as demonstrated for B. macerans CGTase (Kim et al. 2003). Cross-linking can also be performed in the presence of substrate/product molecules, known as molecular imprinting, were one tries to fixate a productive conformation of an enzyme. Molecular imprinting of Paenibacillus sp. A11 and Bacillus macerans CGTase with $\gamma$-CD yielded CGTase crystals that converted over $10 \%$ of starch into CDs larger than $\gamma$-CD (Kaulpiboon et al. 2007), while the corresponding wild-type does not produce these large CDs.

Closely related to the chemical modification method is the immobilization of enzymes onto particles to facilitate the recovery of the expensive biocatalyst from product streams for reuse of the expensive biocatalyst. In addition, immobilization usually stabilizes the biocatalyst under industrial settings. A small number of reports have described the immobilization of CGTases covalently to supports, such as Eupergit C (Martin et al. 2003) and glyoxyl-agarose (Ferrarotti et al. 2006), or by entrapment in sodium alginate beads (Arya and Srivastava 2006). Covalent immobilization is, generally, more favorable as the biocatalyst is not leaking away, but unfortunately, this typically reduces the activity of CGTase to below $10 \%$ due to the inaccessibility of a large portion of the immobilized enzyme for the polymeric substrate. One report describes an 
Table 1 Characterized CGTases and their $\mathrm{CD}$ specificity
${ }^{\text {a }}$ CGTase purified from host organism, but the gene has not been identified and sequenced

${ }^{\mathrm{b}}$ Also known as Paenibacillus macerans

${ }^{\mathrm{c}}$ Also known as Geobacillus stearothermophilus $\mathrm{NO} 2$

${ }^{\mathrm{d}}$ Formation of $\alpha$ - and $\gamma \mathrm{CD}$ was not assayed

\begin{tabular}{|c|c|c|}
\hline Strain & Main CD produced & Reference \\
\hline \multicolumn{3}{|l|}{ Archaea } \\
\hline Pyrococcus furiosus DSM 3638 & $\beta$ & (Lee et al. 2007) \\
\hline Thermococcus kodakaraensis KOD1 & $\beta$ & (Rashid et al. 2002) \\
\hline Thermococcus sp. B1001 & $\alpha$ & (Hashimoto et al. 2001) \\
\hline \multicolumn{3}{|l|}{ Bacteria } \\
\hline Alkalophilic Bacillus agaradhaerens LS-3C & $\beta$ & (Martins et al. 2003a) \\
\hline Alkalophilic Bacillus sp. 1-1 & $\beta$ & (Schmid et al. 1988) \\
\hline Alkalophilic Bacillus sp. 17-1 & $\beta$ & (Kaneko et al. 1989) \\
\hline Alkalophilic Bacillus sp. 38-2 & $\beta$ & (Hamamoto and Kaneko 1987) \\
\hline Alkalophilic Bacillus sp. 1011 & $\beta$ & (Kimura et al. 1987) \\
\hline Alkalophilic Bacillus sp. 8SB ${ }^{\mathrm{a}}$ & $\beta$ & (Atanasova et al. 2008) \\
\hline Alkalophilic Bacillus sp. $20 \mathrm{RF}^{\mathrm{a}}$ & $\beta$ & (Atanasova et al. 2008) \\
\hline Alkalophilic Bacillus sp. A2-5a & $\beta$ & (Ohdan et al. 2000) \\
\hline Alkalophilic Bacillus sp. G-825-6 & $\gamma$ & (Hirano et al. 2006) \\
\hline Alkalophilic Bacillus sp. I-5 & $\beta$ & (Shim et al. 2004) \\
\hline Anaerobranca gottschalkii & $\alpha$ & (Thiemann et al. 2004) \\
\hline Bacillus circulans 8 & $\beta$ & (Nitschke et al. 1990) \\
\hline Bacillus circulans 251 & $\beta$ & (Lawson et al. 1994) \\
\hline Bacillus circulans A11 & $\beta$ & (Rimphanitchayakit et al. 2005) \\
\hline Bacillus circulans DF 9R & $\alpha / \beta$ & (Marechal et al. 1996) \\
\hline Bacillus clarkii 7384 & $\gamma$ & (Takada et al. 2003) \\
\hline Bacillus clausii E16 ${ }^{\mathrm{a}}$ & $\beta$ & (Alves-Prado et al. 2008) \\
\hline Bacillus firmus 290-3 & $\beta / \gamma$ & (Englbrecht et al. 1988) \\
\hline Bacillus firmus $7 \mathrm{~B}^{\mathrm{a}}$ & $\beta$ & (Moriwaki et al. 2007) \\
\hline Bacillus firmus NCIM 5119 & $\beta$ & (Gawande et al. 1999) \\
\hline Bacillus firmus no. $37^{\mathrm{a}}$ & $\beta$ & (Matioli et al. 2001) \\
\hline Bacillus licheniformis & $\alpha / \beta$ & (Hill et al. 1990) \\
\hline Bacillus macerans ${ }^{\mathrm{b}}$ & $\alpha$ & (Takano et al. 1986) \\
\hline Bacillus megaterium $^{\mathrm{a}}$ & $\beta$ & (Pishtiyski et al. 2008) \\
\hline Bacillus obhensis & $\beta$ & (Sin et al. 1991) \\
\hline Bacillus sp. B1018 & $\beta$ & (Itkor et al. 1990) \\
\hline Bacillus sp. BL-31 & $\beta$ & (Go et al. 2007) \\
\hline Bacillus sp. G1 & $\beta$ & (Ong et al. 2008) \\
\hline Bacillus sp. KC201 & $\beta$ & (Kitamoto et al. 1992) \\
\hline Bacillus sp. TS1-1 & $\beta$ & (Rahman et al. 2006) \\
\hline Bacillus stearothermophilus $\mathrm{NO} 2^{\mathrm{c}}$ & $\alpha / \beta$ & (Fujiwara et al. 1992) \\
\hline Brevibacillus brevis CD162 & $\beta$ & (Kim et al. 1998) \\
\hline Geobacillus stearothermophilus ET1 & $\beta$ & (Chung et al. 1998) \\
\hline Klebsiella pneumoniae M5a1 & $\alpha$ & (Binder et al. 1986) \\
\hline Paenibacillus sp. BT01 ${ }^{\mathrm{a}}$ & $\alpha / \beta$ & (Yampayont et al. 2006) \\
\hline Paenibacillus sp. C36 & $\beta$ & (Kinder 2007) \\
\hline Paenibacillus sp. RB01 ${ }^{\mathrm{d}}$ & $\beta$ & (Charoensakdi et al. 2007a) \\
\hline Paenibacillus sp. T16 & $\beta / \gamma^{\mathrm{b}}$ & (Charoensakdi et al. 2007b) \\
\hline Paenibacillus campinasensis $\mathrm{H} 69-3^{\mathrm{a}}$ & $\beta$ & (Alves-Prado et al. 2007) \\
\hline Paenibacillus graminis NC22.13 & $\alpha / \beta$ & (Vollu et al. 2008) \\
\hline Paenibacillus illinoisensis ST-12 $\mathrm{K}^{\mathrm{a}}$ & $\beta$ & (Doukyu et al. 2003) \\
\hline Paenibacillus pabuli US132 & $\beta$ & (Jemli et al. 2008) \\
\hline Thermoanaerobacter sp. 501 & $\alpha / \beta$ & (Norman and Jorgensen 1992) \\
\hline Thermoanaerobacter sp. ATCC 53627 & $\beta$ & (Jørgensen et al. 1997) \\
\hline Thermoanaerobacter sp. P4 $4^{\mathrm{a}, \mathrm{d}}$ & $\beta^{\mathrm{a}}$ & (Avci and Donmez 2009) \\
\hline Thermoanaerobacterium thermosulfurigenes EM1 & $\alpha / \beta$ & (Wind et al. 1998) \\
\hline
\end{tabular}


alternative strategy to facilitate the recovery of biocatalyst, namely, entrapping bacterial cells that display CGTases on the surface in polyvinyl-cryogel beads (Martins et al. 2003b). Chemical modification processes can, therefore, provide a means of improving the application range of CGTases in industry.

\section{Protein engineering for improving $C D$ production by CGTases}

The technique of choice for improving enzyme performance by today's protein engineers is directed evolution. This approach, generally, delivers better enzymes than site-directed mutagenesis, which is a consequence of our limited understanding of structure/function relationships of enzymes. Directed evolution involves the construction of thousands to millions of variants of preexisting enzymes, using polymerase-chain-reaction techniques followed by high-throughput screening for better performing biocatalysts (Leemhuis et al. 2009; Kelly et al. 2009a). Sitedirected mutagenesis is, nevertheless, highly valuable for investigating residues selected on basis of 3D structural knowledge or sequence alignments. Moreover, directed evolution and site-directed mutagenesis are frequently combined, randomizing functionally important regions of enzymes via saturation mutagenesis (Reetz et al. 2008).

\section{Stability}

The stability of a biocatalyst is an important factor in industrial applications. Cyclodextrin glucanotransferases are available from both mesophiles and extremophiles (Table 1) allowing selection of a CGTase with an appropriate thermostability. Highly stable CGTases, however, display greater hydrolytic activity on starch than their less stable counterparts (Kelly et al. 2009b). This may result in lower CD yields as hydrolytic products stimulate the degradation of CDs in the coupling reaction. The stability of enzymes with otherwise beneficial properties can be enhanced via protein engineering (Eijsink et al. 2004), but there is only one report were mutagenesis was used to improve the temperature stability of a CGTase. The stability of Bacillus circulans 251 CGTase was raised by engineering a salt bridge on the surface of the B-domain (Leemhuis et al. 2004a). Other site-directed mutagenesis and directed evolution studies have revealed that engineering of CGTases for reaction specificity, generally, delivers variants with reduced thermostability (Kelly et al. 2008a).

The alternative approach is to engineer existing highly stable CGTases towards the desired reaction specificity. The highly thermostable, but highly hydrolytic, Thermoanaerobacterium thermosulfurigenes EM1 CGTase forms large amounts of short oligosaccharides and degrades CDs in the later phases of starch conversion via the coupling reaction. Using directed evolution, a variant of this CGTase (mutant S77P) was engineered that formed almost no hydrolytic products while maintaining native $\mathrm{CD}$ forming activity and stability (Kelly et al. 2008b). Moreover, the coupling activity of this mutant was very low with no degradation of CDs in the later phases of the starch conversion.

\section{CD specificity}

The long standing goal of CGTase engineering is the construction of variants producing a single type of CD only, which is extremely challenging as substrates of various lengths bind along the enzymes surface to allow for circularization of glucan chains. The challenge is to engineer CGTases that only permit the binding of glucan chains of a defined length at the donor subsites prior to covalent glycosyl-intermediate formation and CD formation. Such specific CGTase variants have not yet been engineered, although, $\mathrm{CD}$ ratios are strongly influenced by mutations at the $-3 /-6 /-7$ donor subsites. The $-1 /-2$ donor subsites are crucial for catalytic activity. Strong enzyme-substrate interactions exist at subsite -6 while a lack of these interactions at subsites $-4 /-5$ ensures the binding of a substrate long enough for $\mathrm{CD}$ formation. Engineering CD specificity by mutating conserved acceptor subsites residues of CGTases is not advisable as this typically results in highly hydrolytic CGTases (Table 2) that form small quantities of CDs (Shim et al. 2004; Kelly et al. 2007). Mutating the nonconserved residue 232 (Lys or Ala) at acceptor subsite +2 slightly altered $C D$ ratios but also lowered $C D$ yields (Nakagawa et al. 2006; Kelly et al. 2008a). Figure 3 shows the CGTase residues/regions important for reaction specificity.

Cyclodextrin glucanotransferase 3D structures indicate that in the process of $\mathrm{CD}$ formation, the glucan chain wraps around the Tyr/Phe195 residue (Fig. 3) suggesting that this residue has an important role in determining $\mathrm{CD}$ specificity. Indeed, an Y195W mutation increased the amount of $\gamma$-CD formed by Bacillus ohbensis CGTase (Table 2) and enhanced the ratio of $\gamma$-CD formed by $B$. circulans 8 . In B. circulans 251, CGTase mutant Y195L increased the ratio of $\beta$-CD strongly (Table 2). Thus, the centrally located Tyr/ Phe195 is an important target for engineering CD size specificity, but the effect of a substitution turns out to be different in various CGTases.

Engineering of subsites $-3 /-6 /-7$ has been successful in altering $C D$ specificity of CGTases. Substituting the conserved residues of subsite -6 increased (Y167F, G180L, and N193G) the amount of $\alpha$-CDs produced by B. circulans 251 CGTase (Table 2) (Leemhuis et al. 2002b). A D371R mutation at subsite -3 of $T$. thermosulfurigenes 
Table 2 Mutations affecting reaction and CD product specificity of CGTases ${ }^{\mathrm{a}}$

\begin{tabular}{|c|c|c|c|c|c|}
\hline Position (subsite) & $\begin{array}{l}\text { Residues found in } \\
\text { wild-type CGTases }\end{array}$ & Mutation & $\begin{array}{l}\% \text { conversion of starch } \\
\text { into indicated } \mathrm{CD}\end{array}$ & $\begin{array}{l}\% \text { ratio of indicated } \\
\mathrm{CD}(\%)\end{array}$ & $\begin{array}{l}\text { Hydrolysis } \\
(\mathrm{U} / \mathrm{mg})\end{array}$ \\
\hline \multirow[t]{3}{*}{195 (central) $^{\mathrm{b}}$} & \multirow[t]{3}{*}{$\mathrm{Y}, \mathrm{F}$} & Y195W & $\gamma \mathrm{CD}: 8 \rightarrow 15$ & - & - \\
\hline & & Y195W ${ }^{f}$ & - & $\gamma \mathrm{CD}: 20 \rightarrow 50$ & - \\
\hline & & $\mathrm{Y} 195 \mathrm{~L}^{\mathrm{g}}$ & - & $\beta C D: 64 \rightarrow 86$ & - \\
\hline \multirow[t]{3}{*}{$259(+2)$} & \multirow[t]{3}{*}{$\mathrm{F}, \mathrm{Y}$} & $\mathrm{F} 259 \mathrm{~N}^{\mathrm{h}}$ & - & - & $3 \rightarrow 60$ \\
\hline & & F259I $\mathrm{I}^{\mathrm{i}}$ & - & - & $4 \rightarrow 29$ \\
\hline & & $F 259 E^{j}$ & - & - & $54 \rightarrow 177$ \\
\hline \multirow[t]{2}{*}{$232(+2)$} & \multirow[t]{2}{*}{$\mathrm{K}, \mathrm{A}$} & $\mathrm{K} 232 \mathrm{E}^{\mathrm{t}}$ & $\alpha \mathrm{CD}: 6 \rightarrow 1$ & - & - \\
\hline & & $\mathrm{A} 232 \mathrm{R}^{\mathrm{u}}$ & - & $\gamma \mathrm{CD}: 26 \rightarrow 35$ & - \\
\hline $194(+1)$ & $\mathrm{L}$ & $\mathrm{L} 194 \mathrm{~T}^{\mathrm{k}}$ & - & $\alpha \mathrm{CD}: 10 \rightarrow 2$ & - \\
\hline $230(+1)$ & A & $\mathrm{A} 230 \mathrm{~V}^{1}$ & - & - & $3 \rightarrow 72$ \\
\hline \multirow[t]{2}{*}{$47(-3)$} & \multirow[t]{2}{*}{$\mathrm{R}, \mathrm{K}, \mathrm{H}, \mathrm{T}$} & $\mathrm{H} 47 \mathrm{~T}^{\mathrm{m}}$ & - & $\gamma \mathrm{CD}: 10 \rightarrow 39$ & - \\
\hline & & $\mathrm{R}_{47 \mathrm{Q}^{\mathrm{n}}}$ & - & $\alpha \mathrm{CD}: 17 \rightarrow 8$ & - \\
\hline \multirow[t]{3}{*}{$89(-3)^{\mathrm{c}}$} & \multirow[t]{3}{*}{$\mathrm{Y}, \mathrm{G}, \mathrm{D}, \mathrm{E}, \mathrm{Q}$} & $\mathrm{Y}^{2} 9 \mathrm{~K}^{\mathrm{o}}$ & $\alpha \mathrm{CD}: 15 \rightarrow 19$ & - & - \\
\hline & & $\mathrm{Y} 89 \mathrm{R}^{\circ}$ & $\alpha \mathrm{CD}: 15 \rightarrow 21$ & - & - \\
\hline & & $\mathrm{Y} 89 \mathrm{D}^{\mathrm{r}}$ & $\alpha \mathrm{CD}: 5.6 \rightarrow 6.8$ & - & - \\
\hline \multirow[t]{3}{*}{$371(-3)$} & \multirow[t]{3}{*}{$\mathrm{D}$} & $\mathrm{D} 371 \mathrm{~K}^{\mathrm{o}}$ & $\alpha \mathrm{CD}: 15 \rightarrow 20$ & - & - \\
\hline & & $\mathrm{D} 371 \mathrm{R}^{\mathrm{p}}$ & $\alpha \mathrm{CD}: 9.8 \rightarrow 1.7$ & - & - \\
\hline & & $\mathrm{D} 371 \mathrm{R}^{\mathrm{p}}$ & $\gamma \mathrm{CD}: 4.9 \rightarrow 7.5$ & - & - \\
\hline 167 & & $\mathrm{Y} 167 \mathrm{~F}^{\mathrm{q}}$ & $\alpha \mathrm{CD}: 4.9 \rightarrow 6.7$ & - & - \\
\hline 179 & & $\mathrm{G} 179 \mathrm{~L}^{\mathrm{q}}$ & $\alpha \mathrm{CD}: 4.9 \rightarrow 2.7$ & - & - \\
\hline 180 & & $\mathrm{G} 180 \mathrm{~L}^{\mathrm{q}}$ & $\alpha \mathrm{CD}: 4.9 \rightarrow 5.5$ & - & - \\
\hline $193(-6)$ & $\mathrm{N}$ & $\mathrm{N} 193 \mathrm{G}^{\mathrm{q}}$ & $\alpha \mathrm{CD}: 4.9 \rightarrow 8.2$ & - & - \\
\hline $146(-7)^{\mathrm{c}}$ & $\mathrm{S}, \mathrm{E}, \mathrm{L}, \mathrm{F}$ & $\mathrm{S} 146 \mathrm{P}^{\mathrm{r}}$ & $\alpha \mathrm{CD}: 5.6 \rightarrow 9.6$ & - & - \\
\hline $145-151(-7)$ & & $\Delta 145-151 \rightarrow \mathrm{D}^{\mathrm{k}}$ & - & $\gamma \mathrm{CD}: 20 \rightarrow 40$ & - \\
\hline $146 / 89(-6 /-3)$ & & $\mathrm{S} 146 \mathrm{P} / \mathrm{Y}^{2} 9 \mathrm{D}^{\mathrm{r}}$ & $\alpha \mathrm{CD}: 5.6 \rightarrow 12$ & - & - \\
\hline $77^{\mathrm{d}}$ & S & $\mathrm{S} 77 \mathrm{P}^{\mathrm{s}}$ & - & - & $40 \rightarrow 3$ \\
\hline
\end{tabular}

${ }^{a}$ Numbering follows that of $B$. circulans 251 CGTase. Only the most effective mutations in CGTase engineering are listed

${ }^{\mathrm{b}}$ This is the centrally located residue in the substrate binding groove (Fig. 3)

${ }^{\mathrm{c}}$ Note that the length and conformation of this loop is variable among CGTases

${ }^{\mathrm{d}} \mathrm{S} 77$ is a second shell residue that is important for the orientation of the acid/base catalyst Glu257

${ }^{\mathrm{e}}$ Bacillus ohbensis (Sin et al. 1994)

${ }^{\mathrm{f}}$ B. circulans 8 (Parsiegla et al. 1998)

${ }^{\mathrm{g}}$ B. circulans 251 (Penninga et al. 1995)

${ }^{\mathrm{h}}$ B. circulans 251 (van der Veen et al. 2001)

${ }^{\mathrm{i}}$ Alkalophilic Bacillus sp. I-5 (Shim et al. 2004)

${ }^{\mathrm{j}}$ T. thermosulfurigenes EM1 (Leemhuis et al. 2002a)

${ }^{\mathrm{k}}$ B. circulans 8 (Parsiegla et al. 1998)

${ }^{1}$ B. circulans 251 (Leemhuis et al. 2003d)

${ }^{\mathrm{m}}$ Bacillus sp. G1 (Goh et al. 2009)

${ }^{\mathrm{n}}$ B. circulans 251 (van der Veen et al. 2000a)

${ }^{\circ}$ P. macerans (Li et al. 2009)

${ }^{\mathrm{p}}$ T. thermosulfurigenes EM1 (Wind et al. 1998)

${ }^{\mathrm{q}}$ B. circulans 251 (Leemhuis et al. 2002b)

${ }^{\mathrm{r}}$ B. circulans 251 (van der Veen et al. 2000b)

${ }^{\mathrm{s}}$ T. thermosulfurigenes EM1 (Kelly et al. 2008b), CD forming activity unaffected

${ }^{\mathrm{t}}$ B. circulans 251 (Kelly et al. 2008a)

${ }^{\mathrm{u}}$ Bacillus clarkii 7364 (Nakagawa et al. 2006) 


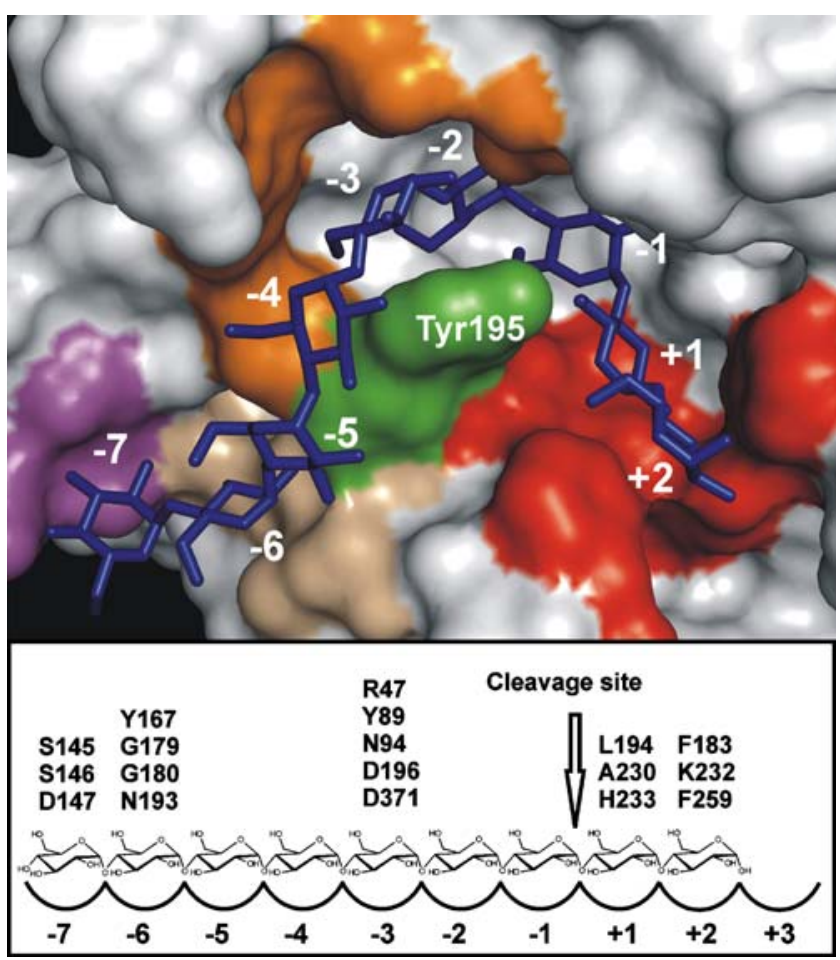

Fig. 3 Substrate binding at the active site of CGTase. The upper panel shows the binding mode of a maltononaose substrate (blue sticks) at the active site of $B$. circulans 251 CGTase (crystal structure 1CXK from the protein data bank). Green-Tyr195; red - subsites $+1 /+2$; orangesubsite -3 ; wheat - subsite -6 ; and magenta-subsite -7 . Figure was created with PyMOL (DeLano 2002). The lower panel gives a schematic overview of the subsites and the residues providing the substrate interactions important for reaction specificity

EM1 CGTase strongly increased $\gamma-\mathrm{CD}$ and lowered $\alpha-\mathrm{CD}$ production (Table 2). In Bacillus sp. G1 a H47T mutation raised the ratio of $\gamma$-CD formed (Table 2), though the total $\gamma$ CD yield was only mildly enhanced. In Paenibacillus macerans mutations $\mathrm{Y} 89 \mathrm{R}$ and $\mathrm{D} 371 \mathrm{~K}$ at subsite -3 enhanced the $\alpha$-CD yield (Table 2). Substrate interactions at subsite -7 are provided by residues from loop 145-151 and are thought to create extra interactions with the seventh sugar residue to favor $\beta-C D$ formation. Removing this loop strongly increased the ratio of $\gamma$-CD produced by $B$. circulans 8 (Table 2). The S146P mutation at subsite -7 , in contrast, increased the conversion of starch into $\alpha$-CDs (Table 2) and in combination with the Y89D substitution at subsite -3 even more $\alpha$-CD was produced (van der Veen et al. 2000b).

Thus, CD ratios and amounts produced by CGTases can be engineered by mutations, but the effects have been studied mostly by incubating starch with the mutant enzymes, which is quite different from industrial process settings. We expect that most mutations will be even more effective under industrial production conditions where continuous precipitation of $\mathrm{CDs}$, etc., selects more for the initial rates of the enzymes, which are generally more affected by the mutations than the final $\mathrm{CD}$ ratios. As described above, our current insights are restricted to knowing many "hotspot" residues for CD size specificity. However, as the polymeric starch substrates interact with at least 9 glucose moieties (Fig. 3), single mutants are not expected to change $\mathrm{CD}$ size specificity completely (see Table 2). Naturally, the extension of recent understanding of CGTase structure/function would fast track the targeting of specific areas for combinatorial site-saturation mutagenesis of the "hotspot" residues followed by high-throughput screening for highly active and CD size specific variants. The screening procedure is, ultimately, the constricting factor in the selection of CD specific CGTase variants. Screening requires a high-throughput HPLC platform to accurately assess the $\mathrm{CD}$ specificity, as the dyes methyl orange, phenolphthalein, and bromocresol green used to reveal the formation of $\alpha-, \beta$-, and $\gamma-\mathrm{CD}$, respectively, show crossreactivity with other $\mathrm{CD}$ sizes. Moreover, as CGTases will eventually breakdown $\mathrm{CDs}$ in the coupling reaction, the amount of CDs produced should be measured at several time points. Thus, the protein engineer must analyze CGTase variants for $\mathrm{CD}$ specificity and percentage of substrate conversion over a number of time points, which should be economically feasible to most laboratories using 96-well format high-throughput HPLC systems.

\section{Baking}

Slowing down the retrogradation of the starch fraction in baked goods is the key to raise their shelf life. This can be accomplished by exo-acting enzymes, such as maltogenic amylase, that partly degrade the exterior of the amylopectin chains during baking process (De Stefanis and Turner 1981). Novamyl, a maltose forming maltogenic amylase, is used commercially as an antistaling enzyme. This enzyme shares $\sim 50 \%$ sequence identity with CGTases, but does not form CDs, although, a few mutations are enough to change it into a CD forming enzyme (Beier et al. 2000). The opposite experiment, changing a CGTase into a maltogenic amylase, was also successful (Leemhuis et al. 2003b). The high similarity of Novamyl with CGTases initiated research to investigate and improve the antistaling properties of CGTases. Protein engineers constructed highly hydrolytic CGTase variants with antistaling properties, using both site-directed mutagenesis (van der Veen et al. 2001; Lee et al. 2002; Leemhuis et al. 2002a) and directed evolution (Shim et al. 2004; Leemhuis et al. 2003d; Kelly et al. 2007). Kelly et al. engineered the most hydrolytic "CGTases" with virtually no CD forming activity (Kelly et al. 2007). All the hydrolytic variants mentioned carry mutations in the residues Phe183, Ala230, or Phe259 at the acceptor subsites $+1 /+2$ and have (strongly) reduced cyclization activities. Recently, a CGTase with improved 
hydrolyzing activity was manipulated for bakers yeast surface display, enhancing the application of these antistaling enzymes in the baking industry (Shim et al. 2007). Increasingly, protein engineers are opening new routes in quality improvements in baking.

\section{CGTases in carbohydrate synthesis}

Oligosaccharides play key roles in living organisms, however, their chemical synthesis remains challenging, explaining the frequent use of enzymes in carbohydrate synthesis (Faijes and Planas 2007; Plou et al. 2007; Homann and Seibel 2009; Kaper et al. 2007). CGTases primarily transfer linear $\alpha$-1,4-glucans to the 4-hydroxyl of glucose or longer $\alpha$-glucans making a new $\alpha-1$, 4-glycosidic bond. Cyclodextrin glucanotransferase can, however, also transfer $\alpha$-1,4-glucans to various other molecules displaying a single glucose moiety or even molecules simply displaying a hydroxyl function. An example of this reaction is the glycosylation of the low calorie sweeter stevioside, to reduce its bitter after-taste (Jung et al. 2007). Table 3 gives a list of compounds glycosylated by CGTases. Glycosylation may increase the water solubility, improve the bifidogenic characteristics, and lower cytotoxicity or improve the shelf life of these compounds. In these acceptor reactions starches, maltodextrins or cyclodextrins are used as the donor substrates and if desired, the attached $\alpha$-glucans maybe trimmed by exo-glycosidases such as $\beta$-amylase or $\alpha$-glucosidase. CGTases have also been applied in the synthesis of long $(>10)$ oligosaccharides using CDs as donor and glucose as acceptor substrate (Yoon and Robyt 2002b). In addition, a donor subsite -1 mutant (H140A) CGTase has been shown to use the potent inhibitor acarbose as substrate and transfers the unnatural $\alpha$-glucan compound acarviosyl (acarviosyl is a pseudo disaccharide composed of C7-cyclitol bound via an imino bridge to 4-amino-4,6-dideoxyglucose) to acceptor sugars (Leemhuis et al. 2004b). This demonstrates that mutant CGTases can be engineered to couple " $\alpha$-glucan" like molecules to acceptor sugars.

Maltotriose and maltotetraose are the shortest natural donor substrates utilized by CGTases, however, CGTase can effectively use short $\alpha$-fluorides of glucose and maltose as donor substrate because they carry an excellent leaving group (Mosi et al. 1997). For example, branched oligosaccharides were synthesized by glycosylation of panose at its 2 free 4-hydroxyl groups using $\alpha$-fluoride maltose (with a protected 4-hydroxyl group) and CGTase as biocatalyst (Greffe et al. 2003). Cyclodextrin glucanotransferases also use $\alpha$-fluoride maltose derivatives where the oxygen atom of the glycosidic linkage was substituted with a carbon or sulfur atom as substrate to synthesize linear and circular
Table 3 Acceptor substrates of CGTase

\begin{tabular}{|c|c|}
\hline Acceptor $^{\mathrm{a}}$ & Reference \\
\hline Acarbose $^{\mathrm{b}}$ & (Yoon and Robyt 2002a) \\
\hline Anhydro-D-fructose ${ }^{c}$ & (Yoshinaga et al. 2003) \\
\hline Arbutin $^{c}$ & (Sugimoto et al. 2003) \\
\hline Ascorbic acid ${ }^{\mathrm{d}}$ & (Jun et al. 2001) \\
\hline Benzo[h]quinazolines ${ }^{\mathrm{e}}$ & (Markosyan et al. 2009) \\
\hline Curcumin $\beta$-D-glucoside ${ }^{c}$ & (Shimoda et al. 2007) \\
\hline Daidzein 7-O- $\beta$-D-glucopyranoside ${ }^{c}$ & (Shimoda et al. 2008b) \\
\hline Genistin $^{\mathrm{c}}$ & (Li et al. 2005) \\
\hline Glycerol $^{\mathrm{f}}$ & (Nakano et al. 2003) \\
\hline $\begin{array}{l}\text { 7-Glycolylpaclitaxel 2-O- } \alpha \text {-D-glu- } \\
\text { copyranoside }^{c}\end{array}$ & (Shimoda et al. 2008a) \\
\hline Hesperidin ${ }^{\mathrm{c}, \mathrm{g}}$ & (Go et al. 2007) \\
\hline Inositol $^{\mathrm{h}}$ & (Sato et al. 1992) \\
\hline Isomaltose $^{c}$ & (Vetter et al. 1992) \\
\hline Luteolin ${ }^{g}$ & (Radu et al. 2006) \\
\hline Naringin ${ }^{c, g}$ & (Go et al. 2007) \\
\hline Pentaerythritol $^{\mathrm{i}}$ & (Nakano et al. 1992) \\
\hline Phenyl $\beta$-D-glucopyranoside ${ }^{c}$ & (Yoon and Robyt 2006) \\
\hline Rutin ${ }^{c, g}$ & (Go et al. 2007) \\
\hline Salicin $^{\mathrm{g}}$ & (Yoon et al. 2004) \\
\hline Saponins $^{c}$ & (Kim et al. 2001) \\
\hline Sorbitol $^{\mathrm{j}}$ & (Park et al. 1998) \\
\hline Stevioside $^{c}$ & $\begin{array}{l}\text { (Kochikyan et al. 2006; Jung et } \\
\text { al. 2007) }\end{array}$ \\
\hline Sucrose $^{\mathrm{c}}$ & (Martin et al. 2004) \\
\hline Sucrose laurate $^{c}$ & (Okada et al. 2007) \\
\hline Trimethylolpropane ${ }^{\mathrm{i}}$ & (Nakano et al. 1992) \\
\hline
\end{tabular}

${ }^{\text {a }}$ More information on the type of hydroxyl group used as acceptor is provided below the table

${ }^{\mathrm{b}}$ Cyclitol (2,3,4-trihydroxyl-5-(hydroxyl)-5,6-cyclohexene

${ }^{\mathrm{c}}$ Glucose moiety

${ }^{\mathrm{d}}$ Hydroxyl of lactone ring

${ }^{\mathrm{e}}$ Primary hydroxyl

${ }^{\mathrm{f}}$ Alcohol

g Phenolic

h 1,2,3,4,5,6-hexahydroxylcyclo-hexane

${ }^{\mathrm{i}}$ Reduced glucose

${ }^{\mathrm{j}}$ Polyol

" $\alpha$-glucans" (Bornaghi et al. 1997). In the near future, we may see an increase in the utilization of engineered (mutant) CGTase in carbohydrate synthesis, as they may have a broader donor and acceptor substrate specificity.

\section{Future CGTases}

Biocatalysis is, generally, regarded as an environment friendly technology. Nevertheless, CD synthesis may 
become even more environmental friendly if CGTase variants can be obtained, either via screening or protein engineering, that effectively convert native starch granules into specific CDs. The long standing aim of CGTase engineering is to construct variants producing a single type of $\mathrm{CD}$. We feel that the current developments in the understanding of CGTase structure/function and advances in CGTase protein engineering will allow the creation of such a desirable catalyst in the coming years, employing combinatorial site-saturation mutagenesis. Moreover, new insights may lead to the design of CGTases forming high amounts of CDs consisting of 9 or more glucose monomers or CGTase variants that are capable of glycosylating, a wide variety of molecules bearing a hydroxyl function.

Acknowledgements HL is supported by the Netherlands Organization for Scientific Research (NWO).

Open Access This article is distributed under the terms of the Creative Commons Attribution Noncommercial License which permits any noncommercial use, distribution, and reproduction in any medium, provided the original author(s) and source are credited.

\section{References}

Alcalde M, Plou FJ, Andersen C, Martin MT, Pedersen S, Ballesteros A (1999) Chemical modification of lysine side chains of cyclodextrin glycosyltransferase from Thermoanaerobacter causes a shift from cyclodextrin glycosyltransferase to $\alpha$-amylase specificity. FEBS Lett 445:333-337

Alcalde M, Plou FJ, Teresa MM, Valdes I, Mendez E, Ballesteros A (2001) Succinylation of cyclodextrin glycosyltransferase from Thermoanaerobacter sp. 501 enhances its transferase activity using starch as donor. J Biotechnol 86:71-80

Alves-Prado HF, Gomes E, da Silva R (2007) Purification and characterization of a cyclomaltodextrin glucanotransferase from Paenibacillus campinasensis strain H69-3. Appl Biochem Biotechnol 137-140:41-55

Alves-Prado HF, Carneiro AA, Pavezzi FC, Gomes E, Boscolo M, Franco CM, da Silva R (2008) Production of cyclodextrins by CGTase from Bacillus clausii using different starches as substrates. Appl Biochem Biotechnol 146:3-13

Arya SK, Srivastava SK (2006) Kinetics of immobilized cyclodextrin glucanotransferase produced by Bacillus macerans ATCC 8244 . Enzyme Microb Technol 39:507-510

Astray G, Gonzalez-Barreiro C, Mejuto JC, Rial-Otero R, SimalGandara J (2009) A review on the use of cyclodextrins in foods. Food Hydrocolloids 23:1631-1640

Atanasova N, Petrova P, Ivanova V, Yankov D, Vassileva A, Tonkova A (2008) Isolation of novel alkaliphilic Bacillus strains for cyclodextrin glucanotransferase production. Appl Biochem Biotechnol 149:155-167

Avci A, Donmez S (2009) A novel thermophilic anaerobic bacteria producing cyclodextrin glycosyltransferase. Process Biochem $44: 36-42$

Beier L, Svendsen A, Andersen C, Frandsen TP, Borchert TV, Cherry JR (2000) Conversion of the maltogenic alpha-amylase Novamyl into a CGTase. Protein Eng 13:509-513
Bender $H$ (1990) Studies of the mechanism of the cyclisation reaction catalysed by the $\alpha$-cyclodextrin glycosyltransferase from Klebsiella pneumoniae M5a1, and the $\beta$-cyclodextrin glycosyltransferase from Bacillus circulans 8. Carbohydr Res 206:257-267

Binder F, Huber O, Bock A (1986) Cyclodextrin-glycosyltransferase from Klebsiella pneumoniae M5a1: cloning, nucleotide sequence and expression. Gene 47:269-277

Biwer A, Antranikian G, Heinzle E (2002) Enzymatic production of cyclodextrins. Appl Microbiol Biotechnol 59:609-617

Blackwood AD, Bucke C (2000) Addition of polar organic solvents can improve the product selectivity of cyclodextrin glycosyltransferase. Solvent effects on CGTase. Enzyme Microb Technol 27:704-708

Bornaghi L, Utille JP, Rekai D, Mallet JM, Sinay P, Driguez H (1997) Transfer reactions catalyzed by cyclodextrin glucosyltransferase using 4-thiomaltosyl and C-maltosyl fluorides as artificial donors. Carbohydr Res 305:561-568

Buchholz K, Seibel J (2008) Industrial carbohydrate biotransformations. Carbohydr Res 343:1966-1979

Cantarel BL, Coutinho PM, Rancurel C, Bernard T, Lombard V, Henrissat B (2009) The Carbohydrate-Active EnZymes database (CAZy): an expert resource for glycogenomics. Nucleic Acids Res 37:D233-D238

Chang HY, Irwin PM, Nikolov ZL (1998) Effects of mutations in the starch-binding domain of Bacillus macerans cyclodextrin glycosyltransferase. J Biotechnol 65:191-202

Charoensakdi R, Iizuka M, Ito K, Rimphanitchayakit V, Limpaseni T (2007a) A recombinant cyclodextrin glycosyltransferase cloned from Paenibacillus sp. strain RB01 showed improved catalytic activity in coupling reaction between cyclodextrins and disaccharides. J Incl Phenom Macrocycl Chem 57:53-59

Charoensakdi R, Murakami S, Aoki K, Rimphanitchayakit V, Limpaseni T (2007b) Cloning and expression of cyclodextrin glycosyltransferase gene from Paenibacillus sp. T16 isolated from hot spring soil in northern Thailand. J Biochem Mol Biol 40:333-340

Chung HJ, Yoon SH, Lee MJ, Kim MJ, Kweon KS, Lee I, Kim JW, Oh BH, Lee HS, Spiridonova VA, Park KH (1998) Characterization of a thermostable cyclodextrin glucanotransferase isolated from Bacillus stearothermophilus ET1. J Agric Food Chem 46:952-959

Costa H, del Canto S, Ferrarotti S, de Jimenez Bonino MB (2009) Structure-function relationship in cyclodextrin glycosyltransferase from Bacillus circulans DF 9R. Carbohydr Res 344:74-79

Dalmia BK, Schutte K, Nikolov ZL (1995) Domain E of Bacillus macerans cyclodextrin glucanotransferase: an independent starch-binding domain. Biotechnol Bioeng 47:575-584

De Stefanis VA, Turner EW (1981) Modified enzyme system to inhibit bread firming method for preparing same and use of same in bread and other bakery products. US Pat 4299848. http://www. uspto.gov/patft/index.html

DeLano WL (2002) The PyMOL molecular graphics system. http:// www.pymol.org

Doukyu N, Kuwahara H, Aono R (2003) Isolation of Paenibacillus illinoisensis that produces cyclodextrin glucanotransferase resistant to organic solvents. Biosci Biotechnol Biochem 67:334-340

Eijsink VGH, Bjork A, Gaseidnes S, Sirevag R, Synstad B, van den Burg B, Vriend G (2004) Rational engineering of enzyme stability. J Biotechnol 113:105-120

Englbrecht A, Harrer G, Lebert M (1988) Biochemical and genetic characterization of a CGTase from an alkalophilic bacterium forming primarily gamma-cyclodextrin. In: Szejtli HO (ed) Proceedings of the fourth international symposium on cyclodextrins. Kluwer, Dordrecht, pp 87-92

Faijes M, Planas A (2007) In vitro synthesis of artificial polysaccharides by glycosidases and glycosynthases. Carbohydr Res 342:15811594 
Fava F, Ciccotosto VF (2002) Effects of randomly methylatedbeta-cyclodextrins (RAMEB) on the bioavailability and aerobic biodegradation of polychlorinated biphenyls in three pristine soils spiked with a transformer oil. Appl Microbiol Biotechnol 58:393-399

Ferrarotti SA, Bolivar JM, Mateo C, Wilson L, Guisan JM, Fernandez-Lafuente R (2006) Immobilization and stabilization of a cyclodextrin glycosyltransferase by covalent attachment on highly activated glyoxyl-agarose supports. Biotechnol Prog 22:1140-1145

Fujiwara S, Kakihara H, Woo KB, Lejeune A, Kanemoto M, Sakaguchi K, Imanaka T (1992) Cyclization characteristics of cyclodextrin glucanotransferase are conferred by the NH2terminal region of the enzyme. Appl Environ Microbiol 58:4016-4025

Gaston JAR, Szerman N, Costa H, Krymkiewicz N, Ferrarotti S (2009) Cyclodextrin glycosyltransferase from Bacillus circulans DF 9R: activity and kinetic studies. Enzyme Microb Technol 45:36-41

Gawande BN, Goel A, Patkar AY, Nene SN (1999) Purification and properties of a novel raw starch degrading cyclomaltodextrin glucanotransferase from Bacillus firmus. Appl Microbiol Biotechnol 51:504-509

Go YH, Kim TK, Lee KW, Lee YH (2007) Functional characteristics of cyclodextrin glucanotransferase from alkalophilic Bacillus sp. BL-31 highly specific for intermolecular transglycosylation of bioflavonoids. J Microbiol Biotechnol 17:1550-1553

Goh KM, Mahadi NM, Hassan O, Rahman RNZRA, Illias RM (2009) A predominant $\beta$-CGTase next term G1 engineered to elucidate the relationship between protein structure and product specificity. J Molecul Catalysis B: Enzymatic 57:270-277

Greffe L, Jensen MT, Bosso C, Svensson B, Driguez H (2003) Chemoenzymatic synthesis of branched oligo- and polysaccharides as potential substrates for starch active enzymes. Chembiochem 4:1307-1311

Haga K, Kanai R, Sakamoto O, Aoyagi M, Harata K, Yamane K (2003) Effects of essential carbohydrate/aromatic stacking interaction with Tyr100 and Phe259 on substrate binding of cyclodextrin glycosyltransferase from alkalophilic Bacillus sp. 1011. J Biochem 134:881-891

Hamamoto T, Kaneko THK (1987) Nucleotide sequence of the cyclomaltodextrin glucanotransferase (CGTase) gene from alkalophilic Bacillus sp. strain no. 38-2. Agric Biol Chem 51:2019-2022

Hashimoto Y, Yamamoto T, Fujiwara S, Takagi M, Imanaka T (2001) Extracellular synthesis, specific recognition, and intracellular degradation of cyclomaltodextrins by the hyperthermophilic archaeon Thermococcus sp. B1001. J Bacteriol 183:5050-5057

Hill DE, Aldape R, Rozzell JD (1990) Nucleotide sequence of a cyclodextrin glucosyltransferase gene, cgtA, from Bacillus licheniformis. Nucleic Acids Res 18:199

Hirano K, Ishihara T, Ogasawara S, Maeda H, Abe K, Nakajima T, Yamagata Y (2006) Molecular cloning and characterization of a novel gamma-CGTase from alkalophilic Bacillus sp. Appl Microbiol Biotechnol 70:193-201

Homann A, Seibel J (2009) Towards tailor-made oligosaccharideschemo-enzymatic approaches by enzyme and substrate engineering. Appl Microbiol Biotechnol 83:209-216

Itkor P, Tsukagoshi N, Udaka S (1990) Nucleotide sequence of the raw starch-digesting amylase gene from Bacillus sp. B1018 and its strong homology to the cyclodextrin glucanotransferase genes. Biochem Biophys Res Commun 166:630-636

Jemli S, Ben ME, Ben MS, Bejar S (2008) The cyclodextrin glycosyltransferase of Paenibacillus pabuli US132 strain: molecular characterization and overproduction of the recombinant enzyme. J Biomed Biotechnol 2008:692573
Jørgensen ST, Tangney M, Starnes RL, Amemiya K, Jørgensen PL (1997) Cloning and nucleotide sequence of a thermostable cyclodextrin glycosyltransferase gene from Thermoanaerobactersp. ATCC 53627 and its expression in Escherichia coli. Biotechnol Lett 19:1027-1031

Jun H-K, Bae K-M, Kim S-K (2001) Production of 2-O- $\alpha-\mathrm{d}-$ glucopyranosyl L-ascorbic acid using cyclodextrin glucanotransferase from Paenibacillus sp. Biotechnol Lett 23:17931797

Jung S-W, Kim T-K, Lee K-W, Lee Y-H (2007) Catalytic properties of $\beta$-cyclodextrin glucanotransferase from alkalophilic Bacillus sp. BL-12 and intermolecular transglycosylation of stevioside. Biotechnol Bioprocess Eng 12:207-212

Kamaruddin K, Illias RM, Aziz SA, Said M, Hassan O (2005) Effects of buffer properties on cyclodextrin glucanotransferase reactions and cyclodextrin production from raw sago (Cycas revoluta) starch. Biotechnol Appl Biochem 41:117-125

Kanai R, Haga K, Yamane K, Harata K (2001) Crystal structure of cyclodextrin glucanotransferase from alkalophilic Bacillus sp. 1011 complexed with 1-deoxynojirimycin at 2.0 A resolution. J Biochem 129:593-598

Kaneko T, Song K, Harmamoto T, Kudo T, Horikoshi K (1989) Construction of a chimeric series of Bacillus cyclodextrin glucanotransferases and analysis of the thermal stability and $\mathrm{pH}$ optima of the enzymes. J Gen Microbiol 135:3447-3457

Kaper T, Leemhuis H, Uitdehaag JC, van der Veen BA, Dijkstra BW, van der Maarel MJE, Dijkhuizen L (2007) Identification of acceptor substrate binding subsites +2 and +3 in the amylomaltase from Thermus thermophilus HB8. Biochemistry 46:5261-5269

Kaulpiboon J, Pongsawasdi P, Zimmermann W (2007) Molecular imprinting of cyclodextrin glycosyltransferases from Paenibacillus sp. A11 and Bacillus macerans with gamma-cyclodextrin. FEBS J 274:1001-1010

Kelly RM, Leemhuis H, Dijkhuizen L (2007) Conversion of a cyclodextrin glucanotransferase into an alpha-amylase: assessment of directed evolution strategies. Biochemistry 46:11216-11222

Kelly RM, Leemhuis H, Gatjen L, Dijkhuizen L (2008a) Evolution toward small molecule inhibitor resistance affects native enzyme function and stability, generating acarbose-insensitive cyclodextrin glucanotransferase variants. J Biol Chem 283:1072710734

Kelly RM, Leemhuis H, Rozeboom HJ, van Oosterwijk N, Dijkstra BW, Dijkhuizen L (2008b) Elimination of competing hydrolysis and coupling side reactions of a cyclodextrin glucanotransferase by directed evolution. Biochem J 413:517-525

Kelly RM, Dijkhuizen L, Leemhuis H (2009a) The evolution of cyclodextrin glucanotransferase product specificity. Appl Microbiol Biotechnol 84:119-133

Kelly RM, Dijkhuizen L, Leemhuis H (2009b) Starch and $\alpha$-glucan acting enzymes, modulating their properties by directed evolution. J Biotechnol 140:184-193

Kim MH, Sohn CB, Oh TK (1998) Cloning and sequencing of a cyclodextrin glycosyltransferase gene from Brevibacillus brevis CD162 and its expression in Escherichia coli. FEMS Microbiol Lett 164:411-418

Kim YH, Lee YG, Choi KJ, Uchida K, Suzuki Y (2001) Transglycosylation to ginseng saponins by cyclomaltodextrin glucanotransferases. Biosci Biotechnol Biochem 65:875-883

Kim W, Chae H, Park C, Lee K (2003) Stability and activity of crosslinking enzyme crystals of cyclodextrin glucanotransferase isolated from Bacillus macerans. J Molec Catalys B: Enzymatic 26:287-292

Kimura K, Kataoka S, Ishii Y, Takano T, Yamane K (1987) Nucleotide sequence of the beta-cyclodextrin glucanotransferase gene of alkalophilic Bacillus sp. 1011 and similarity of its 
amino acid sequence to those of $\alpha$-amylases. J Bacteriol 169:4399-4402

Kinder SJ (2007) Cloning and expression of a bacterial CGTase and impacts of transgenic plants on phytoremediation of organic pollutants. Thesis, Michigan State University

Kitamoto N, Kimura T, Kito Y, Ohmiya K (1992) Cloning and sequencing of the gene encoding cyclodextrin glucanotransferase from Bacillus sp. KC201. J Ferment Bioeng 74:345-351

Klein C, Schulz GE (1991) Structure of cyclodextrin glycosyltransferase refined at 2.0 A resolution. J Mol Biol 217:737-750

Klein C, Hollender J, Bender H, Schulz GE (1992) Catalytic centre of cyclodextrin glycosyltransferase derived from X-ray structure analysis combined with site-directed mutagenesis. Biochemistry 31:8740-8746

Kochikyan VT, Markosyan AA, Abelyan LA, Balayan AM, Abelyan VA (2006) Combined enzymatic modification of stevioside and rebaudioside. Appl Biochem Microbiol 42:31-37

Lawson CL, van Montfort R, Strokopytov B, Rozeboom HJ, Kalk KH, de Vries GE, Penninga D, Dijkhuizen L, Dijkstra BW (1994) Nucleotide sequence and X-ray structure of cyclodextrin glycosyltransferase from Bacillus circulans 251 in a maltosedependent crystal form. J Mol Biol 236:590-600

Lee YD, Kim HS (1992) Effect of organic solvents on enzymatic production of cyclodextrins from unliquefied corn starch in an attrition bioreactor. Biotechnol Bioeng 39:977-983

Lee SH, Kim YW, Lee S, Auh JH, Yoo SS, Kim TJ, Kim JW, Kim ST, Rho HJ, Choi JH, Kim YB, Park KH (2002) Modulation of cyclizing activity and thermostability of cyclodextrin glucanotransferase and its application as an antistaling enzyme. J Agric Food Chem 50:1411-1415

Lee MH, Yang SJ, Kim JW, Lee HS, Kim JW, Park KH (2007) Characterization of a thermostable cyclodextrin glucanotransferase from Pyrococcus furiosus DSM3638. Extremophiles 11:537-541

Leemhuis H, Dijkstra BW, Dijkhuizen L (2002a) Mutations converting cyclodextrin glycosyltransferase from a transglycosylase into a starch hydrolase. FEBS Lett 514:189-192

Leemhuis H, Uitdehaag JCM, Rozeboom HJ, Dijkstra BW, Dijkhuizen L (2002b) The remote substrate binding subsite-6 in cyclodextringlycosyltransferase controls the transferase activity of the enzyme via an induced-fit mechanism. J Biol Chem 277:1113-1119

Leemhuis H, Dijkstra BW, Dijkhuizen L (2003a) Thermoanaerobacterium thermosulfurigenes cyclodextrin glycosyltransferase: mechanism and kinetics of inhibition by acarbose and cyclodextrins. Eur J Biochem 270:155-162

Leemhuis H, Kragh KM, Dijkstra BW, Dijkhuizen L (2003b) Engineering cyclodextrin glycosyltransferase into a starch hydrolase with a high exo-specificity. J Biotechnol 103:203212

Leemhuis H, Rozeboom HJ, Dijkstra BW, Dijkhuizen L (2003c) The fully conserved Asp residue in conserved sequence region I of the alpha-amylase family is crucial for the catalytic site architecture and activity. FEBS Lett 541:47-51

Leemhuis H, Rozeboom HJ, Wilbrink M, Euverink GJ, Dijkstra BW, Dijkhuizen L (2003d) Conversion of cyclodextrin glycosyltransferase into a starch hydrolase by directed evolution: the role of alanine 230 in acceptor subsite +1 . Biochemistry 42:7518-7526

Leemhuis H, Rozeboom HJ, Dijkstra BW, Dijkhuizen L (2004a) Improved thermostability of Bacillus circulans cyclodextrin glycosyltransferase by the introduction of a salt bridge. Proteins 54:128-134

Leemhuis H, Wehmeier UF, Dijkhuizen L (2004b) Single amino acid mutations interchange the reaction specificities of cyclodextrin glycosyltransferase and the acarbose-modifying enzyme acarviosyl transferase. Biochemistry 43:13204-13213

Leemhuis H, Kelly RM, Dijkhuizen L (2009) Directed evolution of enzymes: library screening strategies. IUBMB Life 61:222-228
Li D, Roh SA, Shim JH, Mikami B, Baik MY, Park CS, Park KH (2005) Glycosylation of genistin into soluble inclusion complex form of cyclic glucans by enzymatic modification. J Agric Food Chem 53:6516-6524

Li Z, Wang M, Wang F, Gu Z, Du G, Wu J, Chen J (2007) $\gamma$-Cyclodextrin: a review on enzymatic production and applications. Appl Microbiol Biotechnol 77:245-255

Li Z, Zhang J, Wang M, Gu Z, Du G, Li J, Wu J, Chen J (2009) Mutations at subsite-3 in cyclodextrin glycosyltransferase from Paenibacillus macerans enhancing $\alpha$-cyclodextrin specificity. Appl Microbiol Biotechnol 83:483-490

Loftsson T, Duchene D (2007) Cyclodextrins and their pharmaceutical applications. Int J Pharm 329:1-11

Machovic M, Janecek S (2006) Starch-binding domains in the post-genome era. Cell Mol Life Sci 63:2710-2724

Marechal LR, Rosso AM, Marechal MA, Krymkiewicz N, Ferrarotti SA (1996) Some properties of a cyclomaltodextrin-glucanotransferase from Bacillus circulans DF9R type. Cell Mol Biol 42:659-664

Markosyan AA, Abelyan LA, Markosyan AI, Abelyan VA (2009) Transglycosylation of benzo[h]quinazolines. Appl Biochem Microbiol 45:130-136

Martin Del Valle EMM (2009) Cyclodextrins and their uses: a review. Process Biochem 39:1033-1046

Martin MT, Alcalde M, Plou FJ, Dijkhuizen L, Ballesteros A (2001) Synthesis of malto-oligosaccharides via the acceptor reaction catalyzed by cyclodextrin glycosyltransferases. Biocatal Biotransform 19:21-35

Martin MT, Plou FJ, Alcalde M, Ballesteros A (2003) Immobilization on Eupergit $\mathrm{C}$ of cyclodextrin glucosyltransferase (CGTase) and properties of the immobilized biocatalyst. J Molecul Catalysis B: Enzymatic 21:299-308

Martin MT, Cruces A, Alcalde M, Plou FJ, Bernabe M, Ballesteros A (2004) Synthesis of maltooligosyl fructofuranosides catalyzed by immobilized cyclodextrin glucosyltransferase using starch as donor. Tetrahedron 60:529-534

Martins RF, Delgado O, Hatti-Kaul R (2003a) Sequence analysis of cyclodextrin glycosyltransferase from the alkaliphilic Bacillus agaradhaerens. Biotechnol Lett 25:1555-1562

Martins RF, Plieva FM, Santos A, Hatti-Kaul R (2003b) Integrated immobilized cell reactor-adsorption system for beta-cyclodextrin production: a model study using PVA-cryogel entrapped Bacillus agaradhaerens cells. Biotechnol Lett 25:1537-1543

Matioli G, Zanin GM, de Moraes FF (2000) Enhancement of selectivity for producing $\gamma$-cyclodextrin. Appl Biochem Biotechnol 8486:955-962

Matioli G, Zanin GM, de Moraes FF (2001) Characterization of cyclodextrin glycosyltransferase from Bacillus firmus strain no. 37. Appl Biochem Biotechnol 91-93:643-654

Moriwaki C, Costa GL, Pazzetto R, Zanin GM, Moraes FF, Portilho M, Matioli G (2007) Production and characterization of a new cyclodextrin glycosyltransferase from Bacillus firmus isolated from Brazilian soil. Process Biochem 42:1384-1390

Mosi R, He S, Uitdehaag J, Dijkstra BW, Withers SG (1997) Trapping and characterization of the reaction intermediate in cyclodextrin glycosyltransferase by use of activated substrates and a mutant enzyme. Biochemistry 36:9927-9934

Nakagawa Y, Takada M, Ogawa K, Hatada Y, Horikoshi K (2006) Site-directed mutations in alanine 223 and glycine 255 in the acceptor site of $\gamma$-cyclodextrin glucanotransferase from Alkalophilic Bacillus clarkii 7364 affect cyclodextrin production. J Biochem 140:329-336

Nakamura A, Haga K, Yamane K (1993) Three histidine residues in the active center of cyclodextrin glucanotransferase from alkalophilic Bacillus sp. 1011 effects of the replacement on $\mathrm{pH}$ dependence and transition-state stabilization. Biochemistry 32:6624-6631 
Nakano H, Kitahata S, Tominaga Y, Kiku Y, Ando K, Kawahashi Y, Takenishi S (1992) Syntheses of glucosides with trimethylolpropane and two related polyol moieties by cyclodextrin glucanotransferase and their esterification by lipase. J Ferment Bioeng 73:237-238

Nakano H, Kiso T, Okamoto K, Tomita T, Manan MB, Kitahata S (2003) Synthesis of glycosyl glycerol by cyclodextrin glucanotransferases. J Biosci Bioeng 95:583-588

Nitschke L, Heeger K, Bender H, Schulz GE (1990) Molecular cloning, nucleotide sequence, and expression in Escherichia coli of the $\beta$-cyclodextrin glycosyltransferase gene from Bacillus circulans no. 8. Appl Microbiol Biotechnol 33:542-546

Norman BE, Jorgensen ST (1992) Thermoanaerobacter sp. CGTase: its properties and application. Denpun Kagaku 39:101-108

Ohdan K, Kuriki T, Okada S (2000) Cloning of the cyclodextrin glucanotransferase gene from alkalophilic Bacillus sp. A2-5a and analysis of the raw starch-binding domain. Appl Microbiol Biotechnol 53:430-434

Okada K, Zhao H, Izumi M, Nakajima S, Baba N (2007) Glucosylation of sucrose laurate with cyclodextrin glucanotransferase. Biosci Biotechnol Biochem 71:826-829

Ong RM, Goh KM, Mahadi NM, Hassan O, Rahman RN, Illias RM (2008) Cloning, extracellular expression and characterization of a predominant beta-CGTase from Bacillus sp. G1 in E. coli. J Ind Microbiol Biotechnol 35:1705-1714

Pajatsch M, Andersen C, Mathes A, Bock A, Benz R, Engelhardt H (1999) Properties of a cyclodextrin-specific, unusual porin from Klebsiella oxytoca. J Biol Chem 274:25159-25166

Park KH, Kim MJ, Lee HS, Han NS, Kim D, Robyt JF (1998) Transglycosylation reactions of Bacillus stearothermophilus maltogenic amylase with acarbose and various acceptors. Carbohydr Res 313:235-246

Parsiegla G, Schmidt AK, Schulz GE (1998) Substrate binding to a cyclodextrin glycosyltransferase and mutations increasing the $\gamma$-cyclodextrin production. Eur J Biochem 255:710-717

Penninga D, Strokopytov B, Rozeboom HJ, Lawson CL, Dijkstra BW, Bergsma J, Dijkhuizen L (1995) Site-directed mutations in tyrosine 195 of cyclodextrin glycosyltransferase from Bacillus circulans 251 affect activity and product specificity. Biochemistry 34:3368-3376

Penninga D, van der Veen BA, Knegtel RM, van Hijum SA, Rozeboom HJ, Kalk KH, Dijkstra BW, Dijkhuizen L (1996) The raw starch binding domain of cyclodextrin glycosyltransferase from Bacillus circulans 251. J Biol Chem 271:32777-32784

Pishtiyski I, Popova V, Zhekova B (2008) Characterization of cyclodextrin glucanotransferase produced by Bacillus megaterium. Appl Biochem Biotechnol 144:263-272

Plou FJ, Gomez de Segura A, Ballesteros A (2007) Application of glycosidases and transglycosidases in the synthesis of oligosaccharides. In: Industrial enzymes. Springer, Netherlands, pp 141-157

Qi Q, She X, Endo T, Zimmermann W (2004) Effect of the reaction temperature on the transglycosylation reactions catalyzed by the cyclodextrin glucanotransferase from Bacillus macerans for the synthesis of large-ring cyclodextrins. Tetrahedron 60:799-806

Qi Q, Mokhtar MN, Zimmermann W (2007) Effect of ethanol on the synthesis of large-ring cyclodextrins by cyclodextrin glucanotransferases. J Incl Phenom Macrocycl Chem 57:95-99

Radu OL, Armand S, Lenouvel F, Driguez H, Cimpean A, Iordachescu D (2006) Luteolin glycosylation in organic solvents under catalytic action of cyclodextrin glycosyltransferase from Bacillus circulans. Rev Roum Chim 51:147-152

Rahman K, Illias RM, Hassan O, Mahmood NKN, Rashid NAA (2006) Molecular cloning of a cyclodextrin glucanotransferase gene from alkalophilic Bacillus sp. TS1-1 and characterization of the recombinant enzyme. Enzyme Microb Technol 39:74-84
Rashid N, Cornista J, Ezaki S, Fukui T, Atomi H, Imanaka T (2002) Characterization of an archaeal cyclodextrin glucanotransferase with a novel C-terminal domain. J Bacteriol 184:777-784

Reetz MT, Kahakeaw D, Lohmer R (2008) Addressing the numbers problem in directed evolution. Chembiochem 9:1797-1804

Rendleman JA Jr (1997) Enhancement of cyclodextrin production through use of debranching enzymes. Biotechnol Appl Biochem 26(Pt 1):51-61

Rimphanitchayakit V, Tonozuka T, Sakano Y (2005) Construction of chimeric cyclodextrin glucanotransferases from Bacillus circulans A11 and Paenibacillus macerans IAM1243 and analysis of their product specificity. Carbohydr Res 340:2279-2289

Sato N, Nakamura K, Nagano H, Yagi Y, Koizumi K (1992) Synthesis of glucosyl-inositol using a CGTase, isolation and characterization of the positional isomers, and assimilation profiles for intestinal bacteria. Biotechnol Lett 14:659-664

Schmid G, Englbrecht A, Schimd D (1988) Cloning and nucleotide sequence of a cyclodextrin glycosyltransferase gene from the alkalophilic Bacillus sp.1-1. In: Szejtli HO (ed) Proceedings of the fourth international symposium on cyclodextrins. Kluwer, Dordrecht, pp 77-81

Schmidt AK, Cottaz S, Driguez H, Schulz GE (1998) Structure of cyclodextrin glycosyltransferase complexed with a derivative of its main product $\beta$-cyclodextrin. Biochemistry 37:5909-5915

Shim JH, Kim YW, Kim TJ, Chae HY, Park JH, Cha H, Kim JW, Kim YR, Schaefer T, Spendler T, Moon TW, Park KH (2004) Improvement of cyclodextrin glucanotransferase as an antistaling enzyme by error-prone PCR. Protein Eng Des Sel 17:205-211

Shim JH, Seo NS, Roh SA, Kim JW, Cha H, Park KH (2007) Improved bread-baking process using Saccharomyces cerevisiae displayed with engineered cyclodextrin glucanotransferase. J Agric Food Chem 55:4735-4740

Shimoda K, Hara T, Hamada H, Hamada H (2007) Synthesis of curcumin $\beta$-maltooligosaccharides through biocatalytic glycosylation with Strophanthus gratus cell culture and cyclodextrin glucanotransferase. Tetrahedron Lett 48:4029-4032

Shimoda K, Hamada H, Hamada H (2008a) Chemo-enzymatic synthesis of ester-linked taxol-oligosaccharide conjugates as potential prodrugs. Tetrahedron Lett 49:601-604

Shimoda K, Sato N, Kobayashi T, Hamada H, Hamada H (2008b) Glycosylation of daidzein by the Eucalyptus cell cultures. Phytochemistry 69:2303-2306

Sin K, Nakamura A, Kobayashi K, Masaki H, Uozumi T (1991) Cloning and sequencing of a cyclodextrin glucanotransferase gene from Bacillus ohbensis and its expression in Escherichia coli. Appl Microbiol Biotechnol 35:600-605

Sin KA, Nakamura A, Masaki H, Matsuura Y, Uozumi T (1994) Replacement of an amino acid residue of cyclodextrin glucanotransferase of Bacillus ohbensis doubles the production of $\gamma$-cyclodextrin. J Biotechnol 32:283-288

Son YJ, Rha CS, Park YC, Shin SY, Lee YS, Seo JH (2008) Production of cyclodextrins in ultrafiltration membrane reactor containing cyclodextrin glycosyltransferase from Bacillus macerans. J Microbiol Biotechnol 18:725-729

Stam MR, Danchin EG, Rancurel C, Coutinho PM, Henrissat B (2006) Dividing the large glycoside hydrolase family 13 into subfamilies: towards improved functional annotations of $\alpha$-amylase-related proteins. Protein Eng Des Sel 19:555-562

Sugimoto K, Nishimura T, Nomura K, Sugimoto K, Kuriki T (2003) Syntheses of arbutin- $\alpha$-glycosides and a comparison of their inhibitory effects with those of $\alpha$-arbutin and arbutin on human tyrosinase. Chem Pharm Bull (Tokyo) 51:798-801

Szejlti J, Szente L (2005) Elimination of bitter, disgusting tastes of drugs and foods by cyclodextrins. Eur J Pharm Biopharm 61:115-125

Szente L, Szejtli J (2004) Cyclodextrins as food ingredients. J Food Sci Technol 15:137-142 
Takada M, Nakagawa Y, Yamamoto M (2003) Biochemical and genetic analyses of a novel $\gamma$-cyclodextrin glucanotransferase from an alkalophilic Bacillus clarkii 7364. J Biochem 133:317-324

Takano T, Fukuda M, Monma M, Kobayashi S, Kainuma K, Yamane K (1986) Molecular cloning, DNA nucleotide sequencing, and expression in Bacillus subtilis cells of the Bacillus macerans cyclodextrin glucanotransferase gene. J Bacteriol 166:1118-1122

Terada Y, Yanase M, Takata H, Takaha T, Okada S (1997) Cyclodextrins are not the major cyclic $\alpha-1,4$-glucans produced by the initial action of cyclodextrin glucanotransferase on amylose. J Biol Chem 272:15729-15733

Thiemann V, Donges C, Prowe SG, Sterner R, Antranikian G (2004) Characterisation of a thermoalkali-stable cyclodextrin glycosyltransferase from the anaerobic thermoalkaliphilic bacterium Anaerobranca gottschalkii. Arch Microbiol 182:226-235

Uitdehaag JC, Mosi R, Kalk KH, van der Veen BA, Dijkhuizen L, Withers SG, Dijkstra BW (1999a) X-ray structures along the reaction pathway of cyclodextrin glycosyltransferase elucidate catalysis in the $\alpha$-amylase family. Nat Struct Biol 6:432-436

Uitdehaag JCM, Kalk KH, van der Veen BA, Dijkhuizen L, Dijkstra BW (1999b) The cyclization mechanism of cyclodextrin glycosyltransferase (CGTase) as revealed by a $\gamma$-cyclodextrin-CGTase complex at 1.8-A resolution. J Biol Chem 274:34868-34876

van der Maarel MJEC, van der Veen BA, Uitdehaag JCM, Leemhuis H, Dijkhuizen L (2002) Properties and applications of starchconverting enzymes of the alpha-amylase family. J Biotechnol 94:137-155

van der Veen BA, Uitdehaag JC, Dijkstra BW, Dijkhuizen L (2000a) The role of arginine 47 in the cyclization and coupling reactions of cyclodextrin glycosyltransferase from Bacillus circulans strain 251 implications for product inhibition and product specificity. Eur J Biochem 267:3432-3441

van der Veen BA, Uitdehaag JC, Penninga D, van Alebeek GJ, Smith LM, Dijkstra BW, Dijkhuizen L (2000b) Rational design of cyclodextrin glycosyltransferase from Bacillus circulans 251 to increase $\alpha$-cyclodextrin production. J Mol Biol 296:1027-1038

van der Veen BA, Leemhuis H, Kralj S, Uitdehaag JC, Dijkstra BW, Dijkhuizen L (2001) Hydrophobic amino acid residues in the acceptor binding site are main determinants for reaction mechanism and specificity of cyclodextrin-glycosyltransferase. J Biol Chem 276:44557-44562
Vetter D, Thorn W, Brunner H, Konig WA (1992) Directed enzymatic synthesis of linear and branched gluco-oligosaccharides, using cyclodextrin-glucanosyltransferase. Carbohydr Res 223:61-69

Vollu RE, da Mota FF, Gomes EA, Seldin L (2008) Cyclodextrin production and genetic characterization of cyclodextrin glucanotransferase of Paenibacillus graminis. Biotechnol Lett 30:929-935

Wind RD, Uitdehaag JC, Buitelaar RM, Dijkstra BW, Dijkhuizen L (1998) Engineering of cyclodextrin product specificity and $\mathrm{pH}$ optima of the thermostable cyclodextrin glycosyltransferase from Thermoanaerobacterium thermosulfurigenes EM1. J Biol Chem 273:5771-5779

Yampayont P, Iizuka M, Ito K (2006) Isolation of cyclodextrin producing thermotolerant Paenibacillus sp. from waste of starch factory and some properties of the cyclodextrin glycosyltransferase. J Incl Phenom Macrocycl Chem 56:203-207

Yoon SH, Robyt JF (2002a) Addition of maltodextrins to the nonreducing-end of acarbose by reaction of acarbose with cyclomaltohexaose and cyclomaltodextrin glucanyltransferase. Carbohydr Res 337:509-516

Yoon SH, Robyt JF (2002b) Bacillus macerans cyclomaltodextrin glucanotransferase transglycosylation reactions with different molar ratios of D-glucose and cyclomaltohexaose. Carbohydr Res 337:2245-2254

Yoon SH, Robyt JF (2006) Optimized synthesis of specific sizes of maltodextrin glycosides by the coupling reactions of Bacillus macerans cyclomaltodextrin glucanyltransferase. Carbohydr Res 341:210-217

Yoon SH, Bruce FD, Robyt JF (2004) Enzymatic synthesis of two salicin analogues by reaction of salicyl alcohol with Bacillus macerans cyclomaltodextrin glucanyltransferase and Leuconostoc mesenteroides B-742CB dextransucrase. Carbohydr Res 339:1517-1529

Yoshinaga K, Abe J, Tanimoto T, Koizumi K, Hizukuri S (2003) Preparation and reactivity of a novel disaccharide, glucosyl 1, 5-anhydro-D-fructose (1, 5-anhydro-3-O-alpha-glucopyranosylD-fructose). Carbohydr Res 338:2221-2225

Zhekova B, Dobrev G, Stanchev V, Pishtiyski I (2009) Approaches for yield increase of $\beta$-cyclodextrin formed by cyclodextrin glucanotransferase from Bacillus megaterium. World J Microbiol Biotechnol 25:1043-1049

Zheng M, Endo T, Zimmermann W (2002) Synthesis of large-ring cyclodextrins by cyclodextrin glucanotransferases from bacterial isolates. J Incl Phenom Macrocycl Chem 44:387-390 